\title{
Antibacterial Activity of Indian Borage (Plectranthus amboinicus Benth) Leaf Extracts in Food Systems and Against Natural Microflora in Chicken Meat
}

\author{
Sandeep Kumar Gupta and Pradeep Singh Negi* \\ Fruit and Vegetable Technology Department, CSIR-Central Food Technological Research Institute, \\ Mysore 570020, India \\ Received: November 4, 2014 \\ Accepted: October 21, 2015
}

\begin{abstract}
Summary
The ability of acetone and ethyl acetate extracts of the leaves of a traditional Indian medicinal plant, Indian borage (Plectranthus amboinicus Benth) to prevent spoilage of artificially inoculated model food systems (cabbage and papaya) and natural microflora of chicken meat was evaluated. These extracts were able to reduce the bacterial counts in all food systems; however, the effective concentration varied with the complexity of the system (cabbage $<$ papaya $<$ chicken). A probable mode of action of extracts was investigated by analyzing the changes they cause in bacterial cell wall and leakage of nucleic acid from bacterial cells. Both acetone and ethyl acetate extracts at their respective minimum inhibitory concentrations resulted in leakage of cell constituents to an extent of 40 to 80 and 60 to $95 \%$, respectively, compared to the control, and finally leading to disintegration of cell walls. These findings indicate the potential use of ethyl acetate and acetone extracts of Indian borage leaves in food preservation.
\end{abstract}

Key words: antibacterial activity, cell wall damage, food model system, food safety, Plectranthus amboinicus

\section{Introduction}

Indian borage (Plectranthus amboinicus Benth), also known as country borage, is a medicinal plant used widely in Indian medicine. It is a succulent, aromatic, perennial herb belonging to the family Lamiaceae (1), and decoction of its leaves is used for several medicinal purposes (2). The antimutagenic, antitumorigenic and antigenotoxic effects of Indian borage leaves are well documented (3), and recently its antimicrobial properties have also been reported (4-6).

Increase in the consumer demand for safe and non-synthetic alternatives to chemical preservatives has directed research interest in exploring extracts of various plant materials and several essential oils are being investigated for their biological potency to delay or inhibit the growth of pathogenic and/or toxin-producing microor- ganisms in food $(7,8)$. Several plant extracts have been found to be useful as antimicrobials against spoilage and pathogenic microorganisms. However, their activity decreases considerably when added to a food system (8). Pomegranate peel extracts have been reported to increase the storage life of chicken meat (9), while grape seed and pine bark extracts were successfully used to control the growth of artificially inoculated bacteria in raw ground beef (10). Extracts from cinnamon bark, oregano, clove, pomegranate peel and grape seeds were also reported to decrease various microbial contaminants in raw pork during storage at ambient temperature (11).

Various antimicrobial mechanisms of natural preservatives have been hypothesized. Damage to cytoplasmic membrane and membrane proteins, leakage of intracellular contents, coagulation of cytoplasm, degradation of the 
cell wall, alteration of genetic material and depletion of proton motif force are proposed mechanisms of growth inhibition of microorganisms $(7,8,12)$. Dillenia indica extracts were reported to cause disintegration of cell wall and leakage of genetic material (13). Increase in membrane permeability and leakage of bacterial cell cytoplasm by cinnamaldehyde treatment was documented, wherein cinnamaldehyde interacts with cell wall enzymes $(14,15)$. Phenolic compounds were reported to be the major constituents of various plant extracts, and bacterial cell wall lysis after treatment with phenolics was the main cause of cell death (16).

Although there are numerous studies on antibacterial properties of Indian borage leaf, they mainly focus on methanol extracts. In our earlier study, we found that extracts obtained by sequential acetone and ethyl acetate extraction had higher activity than the methanol extract, and both these extractions individually also had potential antibacterial activity in laboratory conditions $(4,17)$. Therefore, we have used acetone and ethyl acetate extracts of Indian borage leaves to study their antibacterial efficacy in cabbage, papaya and chicken meat, in order to evaluate their antibacterial potency under realistic conditions and establish their usefulness as food preservatives. We have also studied the effect of these extracts on bacterial cell wall and leakage of cell constituents to find their possible antibacterial mechanism.

\section{Materials and Methods}

\section{Plant material and chemicals}

The leaves of Plectranthus amboinicus were collected from the campus of CSIR-Central Food Technological Research Institute (CFTRI), Mysore, India. The plant material was identified at Fruit and Vegetable Technology Department, CFTRI, Mysore, and a specimen voucher was deposited in the Fruit and Vegetable Technology Department herbarium (FVT DH No. LGMGHCC-PA-8/ 2011). All solvents and chemicals used were of analytical reagent grade (Qualigens Fine Chemicals Pvt. Ltd., Mumbai, India), and microbiological media and sterilized plates were from HiMedia (Mumbai, India).

\section{Plant extract preparation}

The fresh leaves of $P$. amboinicus were washed with running tap water and dried at $55{ }^{\circ} \mathrm{C}$ in a hot air oven (Industrial and Laboratory Tools Corp., Chennai, India). The dried leaves were powdered using a mixer grinder (Johnson, Mumbai, India) and extracted with either ethyl acetate or acetone (leaf per solvent ratio of 1:4) to obtain fractions with high antibacterial activity. Flasks were placed in a shaker (60 rpm) for $24 \mathrm{~h}$ at ambient temperature. After $24 \mathrm{~h}$, the extract was filtered with Whatman No. 1 filter paper and the filtrate was concentrated in a fume hood. The chemical profiling of these extracts was undertaken in our earlier study (17). Total phenolics in the acetone extract ( $85.15 \mathrm{mg}$ of gallic acid equivalents per $\mathrm{g}$ of extract) were higher than in the ethyl acetate extract $(67.83 \mathrm{mg} / \mathrm{g})$, and the major phenolics present in acetone and ethyl acetate extract were quercetin (0.193 and 0.142
$\%)$, rutin (0.028 and $0.021 \%)$, coumaric acid (0.014 and $0.010 \%)$, caffeic acid (0.007 and $0.005 \%)$ and gallic acid $(0.003$ and $0.001 \%)$, respectively.

\section{Microorganisms and minimum inhibitory concentra- tion determination}

Bacterial strains, namely Bacillus cereus F 4810 (Public Health Laboratory, London, UK), Staphylococcus aureus FRI 722 (Public Health Laboratory, Amsterdam, The Netherlands), and Escherichia coli MTCC 108 and Yersinia enterocolitica MTCC 859 (both from Microbial Type Culture Collection, Institute of Microbial Technology, Chandigarh, India) were grown overnight in brain heart infusion (BHI) broth at $37{ }^{\circ} \mathrm{C}$. The minimum inhibitory concentration (MIC) of the extracts was determined by agar dilution method (in vitro) in our earlier study (17), and the values were $0.063,0.075,0.063$ and $0.113 \%$ of ethyl acetate extract and $0.038,0.075,0.063$, and $0.100 \%$ of acetone extract against B. cereus, S. aureus, E. coli and Y. enterocolitica, respectively.

\section{Preparation of inoculum}

Overnight cultures of B. cereus, Y. enterocolitica, E. coli and $S$. aureus were harvested by centrifugation at $2111 \times g$ for $10 \mathrm{~min}$. The pellet was washed with $2 \mathrm{~mL}$ of phosphate buffered saline (PBS; $\mathrm{pH}=7.4$ ) and was again centrifuged. Then it was resuspended in $1 \mathrm{~mL}$ of PBS. An aliquot of $30 \mu \mathrm{L}$ of the cell suspension was taken and made up to $3 \mathrm{~mL}$ using PBS. The absorbance of the suspension was read at $620 \mathrm{~nm}$ using UV-Vis spectrophotometer (Shimadzu, Tokyo, Japan) and adjusted to approx. $0.3\left(10^{8}\right.$ $\mathrm{CFU} / \mathrm{mL}$ ) with PBS in order to maintain uniformity in the different sets of experiments.

\section{Application in cabbage food model}

Cabbage food model was prepared by adding finely shredded cabbage to the sterile deionized water $(1: 2$, by mass per volume) and ground in a mixer for 2-3 min (18). The suspension was filtered using muslin cloth and $\mathrm{pH}$ was adjusted to 7.2 using dilute $\mathrm{NaOH}$ /oxalic acid. The juice $(50 \mathrm{~mL})$ was dispensed in $250-\mathrm{mL}$ conical flasks and autoclaved at $121^{\circ} \mathrm{C}$ for $20 \mathrm{~min}$. After cooling, Indian borage extracts were added at different concentrations (MIC or $2 \times \mathrm{MIC})$, and the juice was inoculated with each bacterium separately to obtain a cell density of $10^{5} \mathrm{CFU} / \mathrm{mL}$. Simultaneously, a control without extracts was used and samples were incubated at $37{ }^{\circ} \mathrm{C}$ for 30 days. The juice was withdrawn at regular intervals and appropriate dilution was pour plated onto nutrient agar plates. The colonies developed after incubation at $37{ }^{\circ} \mathrm{C}$ for $24 \mathrm{~h}$ were counted and the count was expressed in $\log \mathrm{CFU} / \mathrm{mL}$.

\section{Application in papaya food model}

After washing with tap water, the exterior surface of the ripe papaya fruit was cotton scrubbed with an alcoholic solution of iodine ( $2 \%$, by mass per volume) and allowed to air dry inside a laminar airflow cabinet. The fruit pulp without seeds $(\mathrm{pH}=5.3)$ was aseptically removed with sterilized spoon, transferred to a sterilized flask and 
homogenized using the spoon. Pulp (50 g) was transferred to sterilized flasks and pasteurized at $80{ }^{\circ} \mathrm{C}$ for 1 min in order to eliminate the background microflora (19). After cooling, the Indian borage extracts were added at different concentrations (MIC or $5 \times \mathrm{MIC}$ ) and the mixture was inoculated with each bacterium separately to obtain cell density of $10^{5} \mathrm{CFU} / \mathrm{g}$. Simultaneously, a control (without extracts) was also used and all the samples were incubated at $37{ }^{\circ} \mathrm{C}$ for 7 days. The pulp was withdrawn at regular intervals and plated using appropriate dilution onto nutrient agar plates. The colonies developed after incubation at $37^{\circ} \mathrm{C}$ for $24 \mathrm{~h}$ were counted and the count was expressed in $\log \mathrm{CFU} / \mathrm{g}$.

\section{Application in chicken meat system}

Chicken meat system was prepared as described by Shan et al. (11). Fresh chicken meat purchased from a local market in Mysore, India was packed in presterilized polyethylene covers and transported immediately in an ice bucket to laboratory. Excess fat and accessory muscles on the surface were trimmed with a sanitized knife under aseptic conditions. The meat was cut into pieces of uniform size and placed in a sterile conical flask. Plant extracts (acetone and ethyl acetate) were added separately at different concentrations $(5 \times \mathrm{MIC}$ or $10 \times \mathrm{MIC})$, mixed thoroughly and incubated for 7 days at $37^{\circ} \mathrm{C}$. Chicken samples without plant extracts were used as control. Sampling was done at regular intervals and natural microflora of chicken meat samples were counted by pour plating of appropriate serial dilutions onto nutrient agar. The count was expressed in $\log$ CFU/g.

\section{Effect of Indian borage leaf extracts on nucleic acid leakage from bacterial cells}

The effect of acetone and ethyl acetate extracts on nucleic acid leakage was estimated as described earlier (20). MIC of the extracts was added to $50 \mu \mathrm{L}$ of the cell suspension $\left(10^{6} \mathrm{CFU}\right)$, the volume was made up to $1 \mathrm{~mL}$ using PBS and incubated at $37^{\circ} \mathrm{C}$. At different time intervals $(0$ (immediately after the addition of extracts), 15, 30 and 60 min), $50 \mu \mathrm{L}$ of mixture were added to $1.95 \mathrm{~mL}$ of PBS and absorbance was measured at $260 \mathrm{~nm}$ against blank (PBS) in a UV-Vis spectrophotometer. For control, only cell suspension $(50 \mu \mathrm{L})$ was added to $1.95 \mathrm{~mL}$ of PBS and read as above. The leakage of nuclear material to the incubating medium was measured by the change of $A_{260 \mathrm{~nm}}$ at each incubation period.

\section{Effect of borage extracts on bacterial cell wall}

Scanning electron microscopy (SEM) was used to visualize the effect of extracts on bacterial cell wall (21). Overnight cultures were centrifuged at $4138 \times g$ and $4{ }^{\circ} \mathrm{C}$ for $10 \mathrm{~min}$ in a refrigerated centrifuge (Plasto Craft, Mumbai, India), washed twice with $0.1 \mathrm{M}$ phosphate buffer $(\mathrm{pH}=6.5)$ and volume was made up to $0.5 \mathrm{~mL}$ with the same buffer. After the addition of the MIC of the extracts, final volume was made up to $1 \mathrm{~mL}$ using phosphate buffer. The above cell suspension was incubated for $1 \mathrm{~h}$ and the cells were harvested at $3040 \times g$ and $4{ }^{\circ} \mathrm{C}$ for $10 \mathrm{~min}$. The pellet was incubated in $1 \%$ glutaraldehyde at $0{ }^{\circ} \mathrm{C}$ overnight and the cells were harvested at $3040 \times g$ and $4{ }^{\circ} \mathrm{C}$ for $10 \mathrm{~min}$. The cells were dehydrated in ethanol gradient (10-100 \%) and coated with thin layer of gold using Polaron SEM coating system (Quorum Technologies Ltd, Lewes, UK). The cells were observed with a LEO $435 \mathrm{VP}$ scanning electron microscope (Leo Electron Microscopy Ltd., Cambridge, UK) and images were exported in TIFF format.

\section{Statistical analysis}

All the experiments to evaluate antimicrobial efficacy of extracts in food systems and leakage of absorbing material measured at $260 \mathrm{~nm}$ were done in triplicate. Statistical analysis of the results was done in Microsoft Excel (Microsoft Corp., Redmond, WA, USA). The significance of the results was based on the difference of the mean value of the treated samples and the control using $t$-test at $\alpha=0.05$.

\section{Results}

\section{Antibacterial effect of Indian borage leaf extracts in food models}

The antibacterial effect of Indian borage leaf extracts was tested against E. coli, S. aureus, B. cereus and Y. enterocolitica by artificially inoculating them (approx. $5 \log$ CFU) in cabbage and papaya models (Figs. 1 and 2). At the same time, the extracts were used in chicken meat to study the effect against natural microflora (Fig. 3). In cabbage food model, $2 \times \mathrm{MIC}$ treatment of extracts resulted in lower viable counts of all bacteria than in control (Fig. 1). However, no definite trend was observed, as MIC and $2 \times \mathrm{MIC}$ of both extracts significantly $(\mathrm{p}<0.05)$ decreased the counts of $B$. $\mathrm{Ce}$ reus, whereas only ethyl acetate extract at $2 \times \mathrm{MIC}$ lowered the counts of $E$. coli throughout storage. $2 \times$ MIC of both extracts caused a significant $(\mathrm{p}<0.05)$ decrease of the count of S. aureus after 7 days, and $2 \times \mathrm{MIC}$ of ethyl acetate extract decreased the count of $Y$. enterocolitica after 7 and 14 days (Fig. 1). Almost similar trend of reduction in bacterial population was observed in papaya model (Fig. 2) albeit at a higher concentration. Both extracts at $5 \times \mathrm{MIC}$ caused a significant $(p<0.05)$ decrease in the count of $Y$. enterocolitica and $S$. aureus in papaya model throughout the storage, whereas $5 \times$ MIC of both extracts caused a significant decrease of bacterial count of B. cereus up to 3 days and of $E$. coli up to 2 days. In case of $S$. aureus, $5 \times$ MIC of acetone extract was able to reduce significantly the counts throughout storage, whereas ethyl acetate extract reduced the counts only up to 5 days at a similar concentration. Both extracts at $5 \times$ MIC reduced significantly $(\mathrm{p}<0.05)$ the counts of Y. enterocolitica throughout storage (Fig. 2). There was no significant difference in bacterial population in MIC- and $2 \times$ MIC-treated papaya samples (data not presented for $2 \times \mathrm{MIC}$ ). In chicken meat, the count of natural microflora was reduced significantly $(\mathrm{p}<0.05)$ by $5 \times \mathrm{MIC}$ and $10 \times \mathrm{MIC}$ of both extracts during storage (Fig. 3). No definite trend was observed of the reduction of bacterial counts by $5 \times \mathrm{MIC}$ and $10 \times$ MIC of both extracts during storage. However, $5 \times$ MIC of ethyl acetate and $10 \times$ MIC of both extracts reduced the growth to approx. $1 \log \mathrm{CFU} / \mathrm{g}$ after 5 days. 

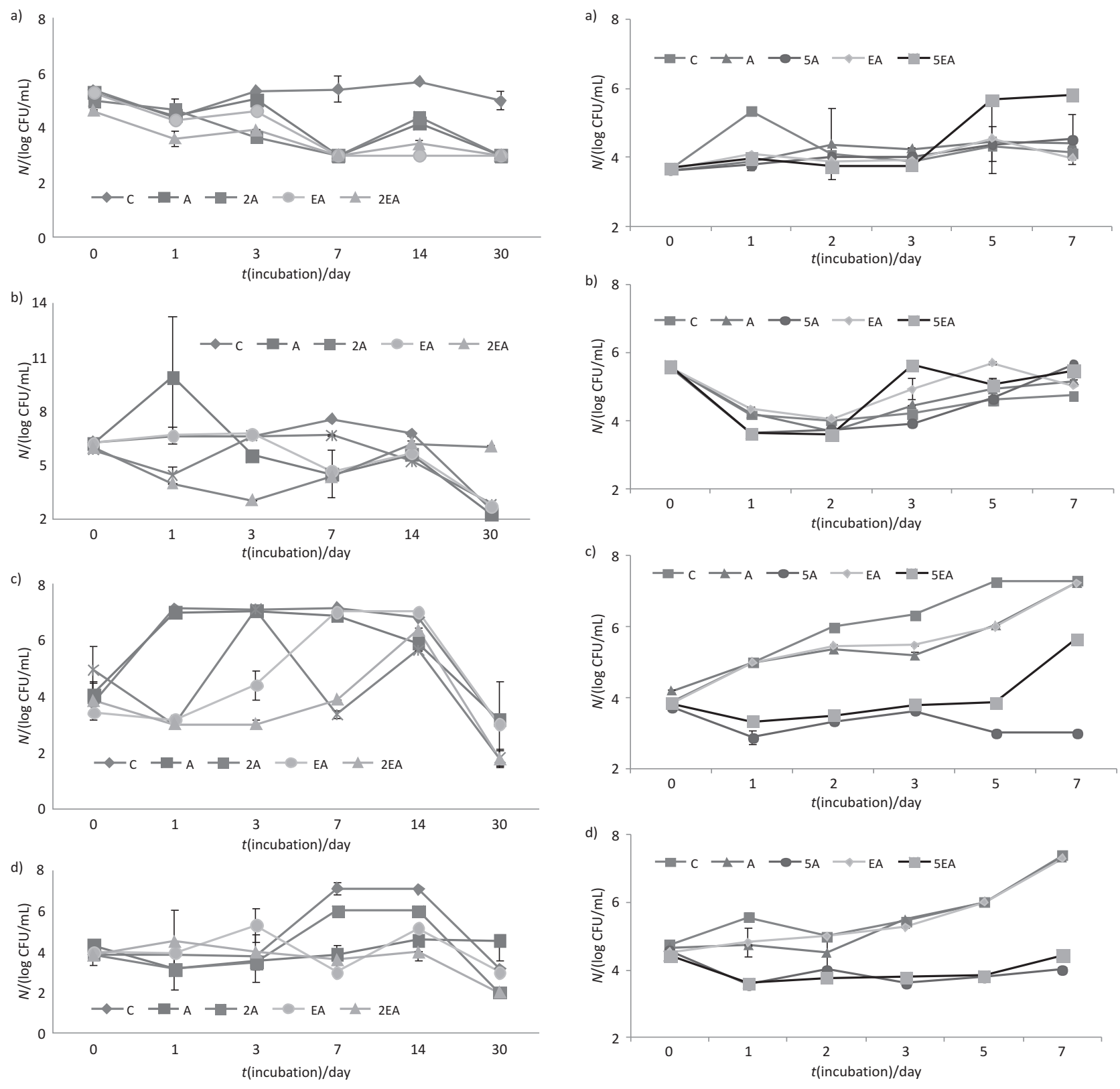

Fig. 1. Effect of Indian borage leaf extracts on the growth of bacteria in cabbage: a) B. cereus, b) E. coli, c) S. aureus, d) Y. enterocolitica. $\mathrm{C}=$ control, $\mathrm{A}=\mathrm{MIC}$ of acetone extract, $2 \mathrm{~A}=2 \times \mathrm{MIC}$ of acetone extract, EA=MIC of ethyl acetate extract, $2 \mathrm{EA}=2 \times \mathrm{MIC}$ of ethyl acetate extract. $\mathrm{MIC}=$ minimum inhibitory concentration

\section{Influence of borage extracts on nucleic acid leakage from bacterial cells}

In the present study, the leakage of 260-nm-absorbing material from bacterial cells (Fig. 4) was observed after treatment with MIC of ethyl acetate and acetone extracts of Indian borage leaves. The increase in $A_{260 \mathrm{~nm}}$ was 60-95 $\%$ when using ethyl acetate extract and $40-80 \%$ when using acetone extract in comparison with control. The observed leakage was significantly $(\mathrm{p}<0.05)$ higher in the treated cells of B. cereus, Y. enterocolitica (except for $60 \mathrm{~min}$ with acetone extracts) and S. aureus (except for 30 and 60 min with both extracts) than that in control. However, that of the treated E. coli cells was statistically $(\mathrm{p}<0.05)$

Fig. 2. Effect of Indian borage leaf extracts on the growth of bacteria in papaya pulp: a) B. cereus, b) E. coli, c) S. aureus, d) Y. enterocolitica. $\mathrm{C}=$ control, $\mathrm{A}=\mathrm{MIC}$ of acetone extract, $5 \mathrm{~A}=5 \times \mathrm{MIC}$ of acetone extract, $\mathrm{EA}=\mathrm{MIC}$ of ethyl acetate extract, $5 \mathrm{EA}=5 \times \mathrm{MIC}$ of ethyl acetate extract. $\mathrm{MIC}=$ minimum inhibitory concentration

similar to the control. Both extracts caused statistically $(\mathrm{p}<0.05)$ similar leakage of $260-\mathrm{nm}$-absorbing material from the tested bacteria at all time intervals, with the exception of $Y$. enterocolitica, where ethyl acetate extract caused statistically $(p<0.05)$ higher leakage than acetone extract after 15 min of incubation (Fig. 4).

\section{Degradation of bacterial cell wall by borage extracts}

Treatment with extracts caused degradation of bacterial cell wall, as can be observed on the scanning electron micrographs of both extracts (Fig. 5). MIC of acetone extract was able to degrade the cell wall of B. cereus and $Y$. enterocolitica, but not many changes were observed in the 


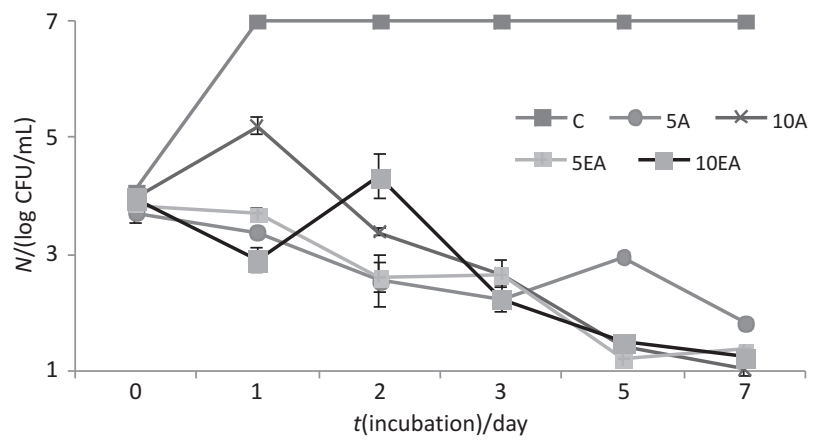

Fig. 3. Effect of Indian borage leaf extracts on the growth of natural microflora in chicken: $\mathrm{C}=$ control, $5 \mathrm{~A}=5 \times \mathrm{MIC}$ of acetone extract, $10 \mathrm{~A}=10 \times \mathrm{MIC}$ of acetone extract, $5 \mathrm{EA}=5 \times \mathrm{MIC}$ of ethyl acetate extract, $10 \mathrm{EA}=10 \times \mathrm{MIC}$ of ethyl acetate extract. $\mathrm{MIC}=$ minimum inhibitory concentration

cell wall of E. coli and S. aureus. The cell wall of untreated cells remained thin and smooth, while loss of smoothness and uniformity was observed in the treated cells. The cell wall was slimy in appearance and its rupture was also observed at MIC of both extracts in B. cereus and Y. enterocolitica, whereas shrinkage of cells was observed in S. aureus and E. coli.

\section{Discussion}

In all food models (Figs. 1-3), there was a marked increase in bacterial population in control samples, whereas the bacterial numbers decreased after treatment with ex- tracts, with certain exceptions. However, the effect of the extract concentration depended on the complexity of a food system. Lower inhibitory activity of the antimicrobial extracts in food models than in in vitro systems as well as differences in inhibitory activity of antimicrobial compounds in different food models have been reported (22). Penteado and Leitão (19) also observed that Listeria monocytogenes growth was not inhibited even at low temperature storage, although a decrease in the count was observed at lower $\mathrm{pH}$. It is well known that the potency of antimicrobial compounds in food systems is reduced when compared to in vitro conditions, as the presence of fats, carbohydrates, proteins, salt and $\mathrm{pH}$ strongly influences the effectiveness of these agents $(23,24)$. Although chitosan, a natural preservative, exerts bactericidal effect against bacteria in a model system, the microflora of apple juice was not inactivated by it, even at higher concentrations (25). Studies on the effect of essential oils in fruit and vegetable products have recorded the effect of foodstuffs on microbial resistance (26) and attributed it to the greater availability of nutrients in foods compared to laboratory media, which may enable bacteria to repair damaged cells faster (27).

The physical structure of a food may also limit the antibacterial efficacy of the extracts. In the present study a higher resistance of microorganisms in papaya pulp (Fig. 2) than in the cabbage model (Fig. 1) was observed. Gutierrez et al. (22) evaluated the efficacy of essential oils of lemon balm, marjoram, oregano and thyme on food models based on lettuce, milk and meat. They reported that food composition and structure had a significant effect on
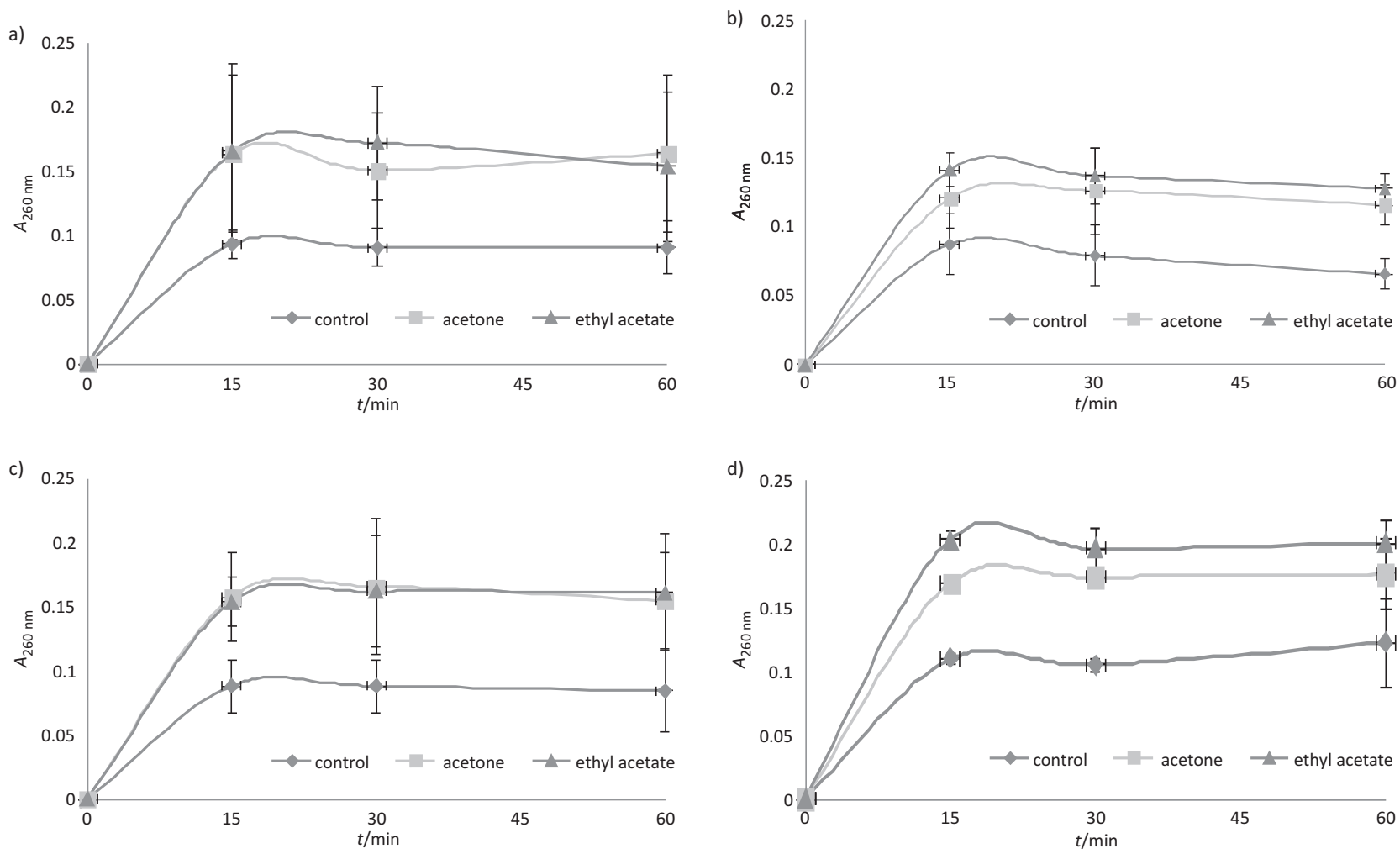

Fig. 4. Effect of Indian borage leaf acetone and ethyl acetate extracts at MIC on the leakage of 260-nm-absorbing material from different bacteria: a) B. cereus, b) E. coli, c) S. aureus and d) Y. enterocolitica. MIC=minimum inhibitory concentration 


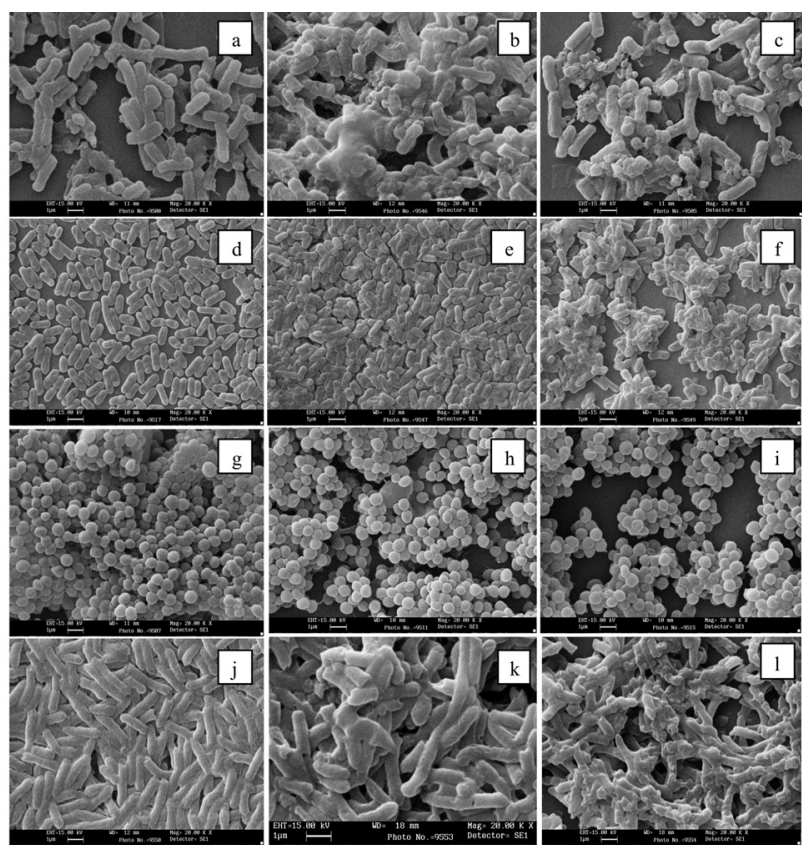

Fig. 5. Effect of Indian borage leaf extracts on B. cereus $(a, b, c)$, E. coli $(\mathrm{d}, \mathrm{e}, \mathrm{f}), \mathrm{S}$. aureus $(\mathrm{g}, \mathrm{h}, \mathrm{i})$ and Y. enterocolitica $(\mathrm{j}, \mathrm{k}, \mathrm{l})$ cell morphology (a, d, g, j=untreated control, b, e, h, k=treated with MIC of acetone extract, c, f, i, l=treated with MIC of ethyl acetate extract). $\mathrm{MIC}=$ minimum inhibitory concentration

the growth of microorganisms. We also observed that, as the complexity of a system increased, the extent of control of microbial population decreased and higher concentration of extract was required for the control of similar bacterial populations (in cabbage $2 \times \mathrm{MIC}$, papaya $5 \times \mathrm{MIC}$, and chicken 10×MIC; Figs. 1-3). A similar trend of reduction of bacterial count in chicken by sea buckthorn leaf extract was reported by Dhanze et al. (28), where the meat treated with $3 \%$ extract was preserved for 7 days as compared to the one treated with $1 \%$ extract (3 days) or untreated meat, which was spoiled after 1 day of storage.

Earlier studies have indicated loss of 260-nm-absorbing material as one of the killing mechanisms and suggested that increase in $A_{260 \mathrm{~nm}}$ of incubation medium may be due to the death of the organism as a consequence of the loss of cytoplasm macromolecules $(29,30)$. In the present study the leakage of $260-\mathrm{nm}$-absorbing material was also observed and most of the leakage occurred during initial period, followed by a slight increase with prolonging the incubation period (Fig. 4). Plant phenolics are known to interact with DNA $(31,32)$; and Hammer et al. (33) observed significant loss of 260-nm-absorbing material in Candida albicans treated with tea tree oil. The leakage of 260-nm-absorbing material from bacterial cells treated with Indian borage extracts observed in the present study may probably be due to the alteration in cell membrane caused by the presence of phenolics (17). Stojković et al. (30) also observed that protocatechuic acid, the main phenolic compound in Veronica montana water extract, inactivates L. monocytogenes by causing permeability changes in cell membrane.

The antibacterial activity of various compounds such as phenols, flavonoids, terpenoids, coumarin and alkaloids present in natural preservatives is due to several mechanisms, including cell wall disintegration and degradation of genetic material (12). In the present study, alteration in cell structure was observed in bacteria treated with Indian borage leaf extracts (Fig. 5). Previously, Carson et al. (20) reported that the content of some cells of $S$. aureus was depleted after treatment with tea tree oil. In our study, both extracts caused rupture of cells in B. cereus and Y. enterocolitica, but ethyl acetate extract caused more structural alterations in $S$. aureus and E. coli. These findings are similar to the earlier reported observations of decrease in the size of Listeria cells by essential oil (34), and structural alterations induced by nitrofuran (31).

\section{Conclusions}

This study showed that Indian borage leaf extracts have good antibacterial activity in different food systems as they reduced the counts of artificially inoculated bacteria in food models (papaya and cabbage) and natural microflora in chicken meat. These extracts probably cause leakage of cell constituents and degradation of bacterial cell wall, thereby decreasing the population of bacteria. However, the concentrations of extracts required for reducing the bacterial counts were high in food models (2to 10 -fold of MIC observed in in vitro system), therefore, the effect of extract addition on sensory and textural properties of foods needs a deeper study.

\section{Acknowledgements}

Authors thank Prof. Ram Rajasekharan, Director, CSIR-CFTRI, Mysore, India, for the constant encouragement, and Dr. M. C. Varadaraj, Chief Scientist, Department of Microbiology and Fermentation Technology, CSIR-CFTRI, Mysore, India, for critically going through the manuscript. The authors wish to express sincere thanks to Mr. A. S. Chauhan, Principal Scientist, Fruit and Vegetable Technology Department, CSIR-CFTRI, Mysore, India, for identification of plant material, and Mr. K. Anbalagan, Senior Technician, Central Instruments Facility and Services, CSIR-CFTRI, Mysore, India, for help in SEM analysis.

\section{References}

1. Kirtikar KR, Basu BD. Indian medicinal plants. Dehradun, India: International Book Distributors; 1999.

2. Lukhoba CW, Simmonds MSJ, Paton AJ. Plectranthus: a review of ethnobotanical uses. J Ethnopharmacol. 2006;103:1-24. http://dx.doi.org/10.1016/j.jep.2005.09.011

3. Annapurani S, Priya R. Antimutagenic, antitumorogenic and antigenotoxic effects of polyphenol extracts of selected medicinal plants. Indian J Nutr Diet. 1999;36:431-5.

4. Bhatt P, Negi PS. Antioxidant and antibacterial activities in the leaf extracts of Indian borage (Plectranthus amboinicus). Food Nutr Sci. 2012;3:146-52.

http://dx.doi.org/10.4236/fns.2012.32022

5. Gurgel APAD, Silva JG da, Grangeiro ARS, Xavier HS, Oliviera RAG de, Pereira MSV, Antibacterial effects of Plectranthus amboinicus [Lour.] Spreng (Lamiaceae) in methicillin resistant Staphylococcus aureus (MRSA). Lat Am J Pharm. 2009;28:460-4.

6. Khare RS, Banerjee S, Kundu K. Coleus aromaticus Benth A nutritive medicinal plant of potential therapeutic value. Int J Pharm Bio Sci. 2011;2:B488-500. 
7. Burt S. Essential oils: their antibacterial properties and potential application in foods - a review. Int J Food Microbiol. 2004;94:223-53.

http://dx.doi.org/10.1016/j.ijfoodmicro.2004.03.022

8. Negi PS. Plant extracts for the control of bacterial growth: efficacy, stability and safety issues for food application. Int J Food Microbiol. 2012;156:7-17. http://dx.doi.org/10.1016/j.ijfoodmicro.2012.03.006

9. Kanatt SR, Chander R, Sharma A. Antioxidant and antimicrobial activity of pomegranate peel extract improves the shelf life of chicken products. Int J Food Sci Technol. 2010; 45:216-22. http://dx.doi.org/10.1111/j.1365-2621.2009.02124.x

10. Ahn J, Grün IU, Mustapha A. Antimicrobial and antioxidant activities of natural extracts in vitro and in ground beef. J Food Protect. 2004;67:148-55.

11. Shan B, Cai YZ, Brooks JD, Corke H. Antibacterial and antioxidant effects of five spice and herb extracts as natural preservatives of raw pork. J Sci Food Agric. 2009;89:1879-85. http://dx.doi.org/10.1002/jsfa.3667

12. Cowan MM. Plant products as antimicrobial agents. Clin Microbiol Rev. 1999;12:564-82.

13. Jaiswal S, Mansa N, Pallavi Prasad MS, Jena BS, Negi PS. Antibacterial and antimutagenic activities of Dillenia indica extracts. Food Biosci. 2014;5:47-53. http://dx.doi.org/10.1016/j.fbio.2013.11.005

14. Ahn J, Grün IU, Mustapha A. Effects of plant extracts on microbial growth, color change, and lipid oxidation in cooked beef. Food Microbiol. 2007;24:7-14. http://dx.doi.org/10.1016/j.fm.2006.04.006

15. Farag RS, Daw ZY, Hewedi FM, El-Baroty GSA. Antimicrobial activity of some Egyptian spice essential oils. J Food Protect. 1989;52:665-7.

16. Borneman WS, Akin DE, VanEseltine WP. Effect of phenolic monomers on ruminal bacteria. Appl Environ Microbiol. 1986;52:1331-9.

17. Gupta SK, Bhatt P, Joseph GS, Negi PS, Varadaraj MC. Phenolic constituents and biological activities of leaf extracts of traditional medicinal plant Plectranthus amboinicus Benth (Lamiaceae). TANG. 2013;3:e32.1-6. http://dx.doi.org/10.5667/tang.2013.0027

18. Francis GA, O'Beirne D. Effects of storage atmosphere on Listeria monocytogenes and competing microflora using a surface model system. Int J Food Sci Technol. 1998;33:465-76. http://dx.doi.org/10.1046/j.1365-2621.1998.00198.x

19. Penteado AL, Leitão MFF. Growth of Listeria monocytogenes in melon, watermelon and papaya pulps. Int J Food Microbiol. 2004;92:89-94. http://dx.doi.org/10.1016/j.ijfoodmicro.2003.08.020

20. Carson CF, Mee BJ, Riley TV. Mechanism of action of Melaleuca alternifolia (tea tree) oil on Staphylococcus aureus determined by time kill, lysis, leakage, and salt tolerance assays and electron microscopy. Antimicrob Agents Chemother. 2002;46:1914-20.

http://dx.doi.org/10.1128/AAC.46.6.1914-1920.2002

21. Moosavy MH, Basti AA, Misaghi A, Salehi TZ, Abbasifar R, Mousavi HAE, et al. Effect of Zataria multiflora Boiss. essential oil and nisin on Salmonella typhimurium and Staphylococcus aureus in a food model system and on the bacterial cell membranes. Food Res Int. 2008;41:1050-7. http://dx.doi.org/10.1016/j.foodres.2008.07.018
22. Gutierrez J, Barry-Ryan C, Bourke P. Antimicrobial activity of plant essential oils using food model media: efficacy, synergistic potential and interactions with food components. Food Microbiol. 2009;26:142-50. http://dx.doi.org/10.1016/j.fm.2008.10.008

23. Smid EJ, Gorris LGM. Natural antimicrobials for food preservation. In: Rahman MS, editor. Handbook of food preservation. New York, NY, USA: Marcel Dekker Inc., 1999. pp. 285-308.

24. Boziaris IS, Proestos C, Kapsokefalou M, Komaitis M. Antimicrobial effect of Filipendula ulmaria plant extract against selected foodborne pathogenic and spoilage bacteria in laboratory media, fish flesh and fish roe product. Food Technol Biotechnol. 2011;49:263-70.

25. Malinowska-Panczyk E, Kolodziejska I, Murawska D, Wolosewicz G. The combined effect of moderate pressure and chitosan on Escherichia coli and Staphylococcus aureus cells suspended in a buffer and on natural microflora of apple juice and minced pork. Food Technol Biotechnol. 2009;47: 202-9.

26. Wan J, Wilcock A, Coventry MJ. The effect of essential oils of basil on the growth of Aeromonas hydrophila and Pseudomonas fluorescens. J Appl Microbiol. 1998;84:152-8. http://dx.doi.org/10.1046/j.1365-2672.1998.00338.x

27. Gill AO, Delaquis P, Russo P, Holley RA. Evaluation of antilisterial action of cilantro oil on vacuum packed ham. Int J Food Microbiol. 2002;73:83-92. http://dx.doi.org/10.1016/S0168-1605(01)00712-7

28. Dhanze H, Khurana SK, Mane BG. Effect of seabuckthorn leaf extract on microbiological quality of raw chicken during extended periods of storage. J Food Qual. 2013;36:59-65. http://dx.doi.org/10.1111/jfq.12007

29. Davidson PM, Naidu AS. Phyto-phenols. In: Naidu AS, editor. Natural food antimicrobial systems. London, UK: CRC Press; 2000. pp. 265-94.

30. Stojković DS, Živković J, Soković M, Glamočlija J, Ferreira ICFR, Janković T, Maksimović Z. Antibacterial activity of Veronica montana L. extract and of protocatechuic acid incorporated in a food system. Food Chem Toxicol. 2013;55:20913. http://dx.doi.org/10.1016/j.fct.2013.01.005

31. Chadfield MS, Hinton MH. Invitro activity of nitrofuran derivatives on growth and morphology of Salmonella enterica serotype Enteritidis. J Appl Microbiol. 2004;96:1002-12. http://dx.doi.org/10.1111/j.1365-2672.2004.02225.x

32. Mongelli E, Pampuro S, Coussio J, Salomon H, Ciccia G. Cytotoxic and DNA interaction activities of extracts from medicinal plants used in Argentina. J Ethnopharmacol. 2000;71: 145-51. http://dx.doi.org/10.1016/S0378-8741(99)00195-6

33. Hammer KA, Carson CF, Riley TV. Antifungal effects of Melaleuca alternifolia (tea tree) oil and its components on Candida albicans, Candida glabrata and Saccharomyces cerevisiae. J Antimicrob Chemother. 2004;53:1081-5. http://dx.doi.org/10.1093/jac/dkh243

34. Rasooli I, Rezaei MB, Allameh A. Ultrastructural studies on antimicrobial efficacy of thyme essential oil on Listeria monocytogenes. Int J Infect Dis. 2006;10:236-41. http://dx.doi.org/10.1016/j.ijid.2005.05.006 